\title{
Grazing impacts on selected soil parameters under short- term forage sequences
}

\author{
E. MAPFUMO, D.S. CHANASYK, V.S. BARON, AND M.A. NAETH
}

Post-doctoral fellow and professor with the Department of Renewable Resources, University of Alberta, Alberta, Canada T6G 2H1, and research scientist with Lacombe Research Centre, Agriculture and Agri-Food Canada, 6000 C\&E Trail, Lacombe, Alberta, Canada T4L 1W1, and professor, Dept. Renewable Resources University of Alberta, Alberta, Canada T6G $2 H 1$.

Corresponding author, Chanasyk, (Email address: david.chanasyk@ualberta.ca; Faxno (780) 492-4323.

\section{Abstract}

Long-term cultivation is known to change soil physical and chemical properties, but little is known about whether shortterm agricultural practices, such as rotational grazing, can initiate such changes. This study investigated the impacts of 3 grazing intensities (heavy, medium, and light) and 4 forages on selected soil physical and chemical parameters of a Typic Haplustoll at Lacombe, Alberta. Measurements were conducted on soil samples collected at the beginning (1993) and the end (1996) of the study. Two perennial forages, smooth bromegrass (Bromus iner mis cv. 'Carlton') and meadow bromegrass (Bromus riparius cv. 'Paddock'), and 2 annuals, a mixture of triticale ( $X$ Triticosecale Wittmack cv. 'Pika') and barley (Hordeum vulgare L. cv. 'AC Lacombe') and triticale alone were used for the study. Grazing intensity or forage species did not affect carbon-to-nitrogen ratio. Grazing intensity influenced changes in available water holding capacity for the 0-5 cm interval, soil nitrogen for the $30-45 \mathrm{~cm}$ interval, soil $\mathrm{pH}$ for the $5 \mathbf{- 1 5} \mathrm{cm}$ interval and electrical conductivity for all depth intervals except for the $0-5 \mathrm{~cm}$ interval $(P \leq$ 0.05). Forage species affected changes in soil carbon in the $0-5 \mathrm{~cm}$ interval, soil pH between 0 and $15 \mathrm{~cm}$, and electrical conductivity between 5 and $45 \mathrm{~cm}(P \leq 0.05)$. Soil electrical conductivities for all grazing levels and forage treatments were within the range (i.e. 0-2 dS m$~^{-1}$ ) considered to have negligible effects on plant growth. The minimal effects of grazing and plant species on soil parameters in this study may have been due to the resilient intrinsic properties of the soil and/or the short study length.

Key Words: Carbon, electrical conductivity, nitrogen, potassium, soil pH

Cultivation accelerates mineralization of organic matter (Broersma 1991) and may consequently alter water retention properties, and carbon (C) and nitrogen (N) content of the soil. Yearly cultivation in annual cropping systems may pulverize soil particles and thus weaken soil structure and render the soil more vulnerable to erosion. Although long-term cultivation is known to change many soil physical and chemical properties (Johnston et al. 1971) as little as 5 years of cropping can initiate such changes (Dormaar et al. 1989, Dormaar and Willms 1990).

Funding from the Canada-Alberta Environmentally Sustainable Agriculture Agreement (CAESA) is gratefully acknowledged. Thanks are extended to David Young, Kelly Ostermann, Pola Genoway, Kirsten Gregorwich and Mae Elsinger for field assistance.

Manuscript accepted 8 Dec. 1999.

\section{Resumen}

Se sabe que el cultivar los terrenos por un largo tiempo cambia la propiedades físicas y químicas del suelo, sin embargo pero poco se sabe acerca de que si la practicas agrícolas de corto plazo, tales como el apacentamiento rotacional, puede iniciar dichos cambios. En este estudio se investigo el impacto de 3 intensidades de apacentamiento (alta, media y ligera) y 4 especies forrajeras en los parámetros físico-químicos de un suelo "Typic Haplustoll" en Lancombe, Alberta. La mediciones se realizaron en muestras de suelo colectadas al inicio (1993) y al final (1996) del estudio. En este experimento se utilizaron dos especies perennes, "Smooth bromegrass" (Bromus inermis cv. 'Carlton') y "Meadow bromegrass" (Bromus riparius cv. 'Paddock') y dos especies anuales, una mezcla de triticale (X Triticosecale Wittmack cv. 'Pika') y cebada (Hordeoum vulgare $\mathrm{L}$. cv. 'AC Lamcombe') y triticale solo. Ni la intensidad de apacentamiento ni las especies vegetales afectaron la relación carbón-nitrógeno. La intensidad de apacentamiento indujo cambios en la capacidad de retención de agua disponible del estrato $\mathrm{de}$ 0-5 $\mathrm{cm}$, en el nitrógeno del suelo del estrato $30-45 \mathrm{~cm}$, en el $\mathrm{pH}$ a la profundidad de 0-15 cm y en la conductividad eléctrica de todos los estratos, excepto el de $0-5 \mathrm{~cm}$ (P\#0.05). Las especies vegetales afectaron el carbón del suelo a la profundidad de $0-5 \mathrm{~cm}$, el pH del estrato 0-15 cm y la conductividad eléctrica del estrato de 5$45 \mathrm{~cm}$ (P\#0.05). Las medidas de conductividad eléctrica del suelo para todas las intensidades del apacentamiento y especies vegetales estuvieron dentro del rango (esto es 0-2 dS m${ }^{-1}$ ) que se con sidera no detrimental para el crecimiento de las plantas. El efecto mínimo de la intensidad de apacentamiento y especies vegetales en los parámetros del suelo medidos en este estudio se pudo deber a las propiedades intrínsecas del suelo para soportar situaciones de disturbio o a que el período de tiempo que comprendió el estudio fue muy corto.

The combined effect of dung and urine depositions with cattle grazing may alter soil acidity (Johnston et al. 1971) and salinity (Chaneton and Lavado 1996), and may also increase the loss of nitrogen via volatilization (Holland and Detling 1990). Furthermore, heavy grazing is known to increase surface soil bulk density (Krenzer et al. 1989, Mapfumo et al. 1999) which may in turn hinder root growth.

Perennial forages reduce soil erosion due to the maintenance of protective cover, improved soil structure and aggregate stability and increased litter on the soil surface. Indeed, most studies of the grazing impacts on soil physical and chemical properties have been conducted on perennial grasses. In many parts of the aspen 
parkland of Alberta, however, pasturing annual crops by swath grazing is being used to extend the grazing season (Lagroix-McLean and Naeth 1997), with annuals such as winter triticale and barley becoming common pasture species (Baron et al. 1993). However, little is known about the direct impacts of grazing of annual forages on soil parameters.

Our working hypothesis considered that grazing differentially impacts particular soil parameters and the extent of impact is related to the intensity of grazing and the type of forage being grazed. The objective of this study was to investigate the effects of heavy, medium and light intensity grazing of annual and perennial forages on soil parameters over a relatively short period of time.

\section{Materials and Methods}

\section{Experimental Design}

The study was conducted at the Lacombe Research Station, Alberta, Canada on a Typic Haplustoll derived from glacio-lacustrine parent material. On average the soil (0-15-cm depth) contained $15 \%$ clay, $34 \%$ silt, and $51 \%$ sand. The experimental design was a randomized complete block with 3 grazing treatments, 4 plant species and 4 replicated blocks, for a total of 48 plots. Plots, $33 \times 9 \mathrm{~m}$, were established in 1992 by tilling a 15-year old growth pasture which had been under extensively managed grazing. The oldgrowth pasture was composed of smooth bromegrass (Bromus inermis L.), Kentucky bluegrass (Poa pratensis L.), quackgrass (Agropyron repens L), bluegrass (Poa spp.) with common occurrences of dandelion (Taraxacum officinale L.).

\section{Plant Species}

The 4 forage species used to seed plots included 'Carlton' smooth bromegrass (Bromis inermis), 'Paddock' meadow bromegrass (Bromus riparius Rehm.), 'Pika' triticale (X Triticosecale Wittmack), or a mixture of 'Pika' triticale/'AC Lacombe' barley (Hordeum vulgare L.). Perennials (i.e. smooth bromegrass and meadow bromegrass) were seeded on 31 May 1993. Smooth bromegrass was seeded at $11.2 \mathrm{~kg} \mathrm{ha}^{-1}$ and meadow bromegrass at $16.8 \mathrm{~kg} \mathrm{ha}^{-1}$. Before seeding the experimental area received a broadcast application of $8,14,26$, and $5 \mathrm{~kg} \mathrm{ha}^{-1}$ of $\mathrm{N}, \mathrm{P}, \mathrm{K}$, and $S$, respectively. In subsequent years, perennial and annual plots were fertilized at the same time. Each spring 100, 22, and $41 \mathrm{~kg} \mathrm{ha}^{-1}$ of $\mathrm{N}, \mathrm{P}$, and $\mathrm{K}$, respectively were broadcast over the experimental area. Annual plots were rototilled each spring to a depth of $10 \mathrm{~cm}$, and seeded to triticale at $135 \mathrm{~kg} \mathrm{ha}^{-1}$ in 2 passes, or triticale at $90 \mathrm{~kg}$ $\mathrm{ha}^{-1}$ and barley $50 \mathrm{~kg} \mathrm{ha}^{-1}$ in separate operations. Plant residue remaining after the last grazing of the previous season was left in place until spring (end of April) seeding. The herbicide, MCPA (2-methyl-4chlorophenoxyacetic acid), was applied to annual plots after the crop emerged at rates of $600 \mathrm{~g}$ a.i. ha ${ }^{-1}$ in 1994 to 1996 . No weed control was used in perennial plots.

\section{Grazing Systems}

Beginning in 1994, up to 6 animals were placed on a treatment at 1 time, depending on the intensity of grazing desired. Each grazing event was less than 24 hours. Forage height was used to define grazing intensity. Forage heights were determined using a disk meter (Bransby et al. 1977) and the average of 10 disk heights was calculated. Averaged over 3 grazing years, the number of grazing events per season for perennials were 7,5 , and 3 for heavy, medium and light grazing, respectively, whereas comparable figures for annuals were 4, 4, and 2 for heavy, medium and light grazing, respectively (Table 1). Averaged over 3 years, mean cow-days per season for perennials was 37,20 , and 16 and for annuals 19, 11, and 8 for heavy, medium and light grazing, respectively. Mean residue levels for perennials averaged over 3 years were $0.89,1.71$, and $2.57 \mathrm{Mg} \mathrm{ha}^{-1}$ and for annuals $0.91,1.22$, and $2.23 \mathrm{Mg} \mathrm{ha}^{-1}$ for heavy, medium and light grazing, respectively.

\section{Soil Sampling}

Soil sampling was conducted prior to grazing in September 1993 using a hand auger to a depth of $60 \mathrm{~cm}$. Sampling at the end of the study was conducted in October 1996 to the same depth using a tractormounted hydraulic auger. For both samplings, three samples per plot were taken and separated into increments of $0-5$, $5-15,15-30,30-45$, and $45-60 \mathrm{~cm}$. All samples were air-dried and ground to pass a $2-\mathrm{mm}$ sieve. Before determination of physical and chemical properties, the 3 samples from the same depth interval and within each plot were mixed to form a composite sample.

\section{Soil Physical and Chemical Properties}

Water retention properties were determined on these disturbed soils using pressure plates (Topp et al. 1993). Field capacity was the gravimetric moisture content retained at a pressure of $0.033 \mathrm{MPa}$ and wilting point was moisture content retained at $1.5 \mathrm{MPa}$. Available water holding capacity (AWHC) was the difference between field capacity moisture and wilting point moisture.

Electrical conductivity (EC) was determined using the saturation extract method (Janzen 1993). Soil pH was determined using distilled water in a soil: water ratio of $1: 2$. Total $\mathrm{C}$ in soil was determined using the Leco carbon analyzer. Initial soil tests did not indicate the presence of free carbonates. Soil samples for determinations of total $\mathrm{N}$ were digested using the standard Kjeldhal method with concentrated sulfuric acid (McGill and Figuerido 1993). Total $N$ concentration was then determined using the autoanalyzer (Technicon Autoanalyzer II). Extractable $\mathrm{K}$ using extractant solution of $1 \mathrm{~N}$ $\mathrm{NH}_{4} \mathrm{OAC}$ adjusted to $\mathrm{pH} 7$ with $\mathrm{NH}_{4} \mathrm{OH}$

Table 1. Number of grazings, cow-days for each grazing season and the total number of cow-days for each grazing intensity and plant species for the entire study period.

\begin{tabular}{lccccccc}
\hline \hline $\begin{array}{l}\text { Grazing } \\
\text { Level }\end{array}$ & \multicolumn{3}{c}{ Number of Grazings } & \multicolumn{3}{c}{ Cow-days } & \multicolumn{2}{c}{ Total } \\
Cow-days
\end{tabular}


or acetic acid (Hendershot et al. 1993) was determined using atomic absorption spectrophotometry.

\section{Statistical Analysis}

To test for significant $(\mathrm{P} \leq 0.05)$ changes in soil parameters, pre- versus post-treatment, a paired t-test was used for each combination of grazing intensity, plant species and soil depth. For individual depths, we tested for significant effects of grazing intensity and plant species on soil parameters with a 2-way ANOVA using the SAS institute generalized linear models procedure (SAS Institute 1989). Change (post-treatment-pre-treatment) in available water holding capacity, organic carbon, total soil nitrogen, extractable potassium, soil $\mathrm{pH}$, and electrical conductivity were dependent variables. Where the F-test indicated a significant $(\mathrm{P} \leq 0.05)$ effect, means were separated using the least significance difference (LSD) test (Gomez and Gomez 1984).

\section{Results}

\section{Water Retention}

For all species and grazing intensities, water contents at field capacity (FC) for soil depths between 0 and $30 \mathrm{~cm}$ ranged

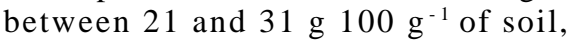
whereas water contents at wilting point

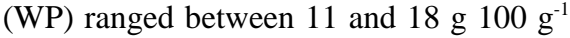
of soil. For depth intervals between 30 and $60 \mathrm{~cm}, \mathrm{FC}$ ranged between 15 and $22 \mathrm{~g}$ $100 \mathrm{~g}^{-1}$ of soil, whereas WP ranged

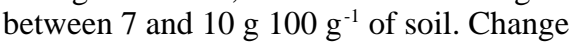
in available water holding capacity (AWHC) after 3 years of grazing was not significantly different among species. For the $0-5 \mathrm{~cm}$ depth interval the heavy grazing intensity had a significantly lower AWHC after 3 years of grazing (Table 2). Change in AWHC for medium and light grazing in the $0-5 \mathrm{~cm}$ interval was positive and significantly greater than that for the heavy grazing. Water retention in light and medium grazing may have increased relative to heavy grazing, possibly because the former treatments had greater organic matter input and incorporation into the soil compared to the latter. In fact results from a concurrent study indicate that the average litter (all dead plant material) mass measured in the fall over 3 years of grazing were $2.8,3.4$, and $5.4 \mathrm{Mg} \mathrm{ha}^{-1}$ for heavy, medium, and light grazing, respectively (Baron et al. 1999). Litter masses measured in spring for the respective grazing treatments were $1.6,2.5$, and $4.2 \mathrm{Mg}$ $\mathrm{ha}^{-1}$. It is also possible that surface soil
Table 2. Change in available water holding

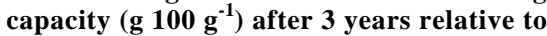
corresponding pre-grazing values under different grazing intensities at different soil depths. Values pooled over plant species.

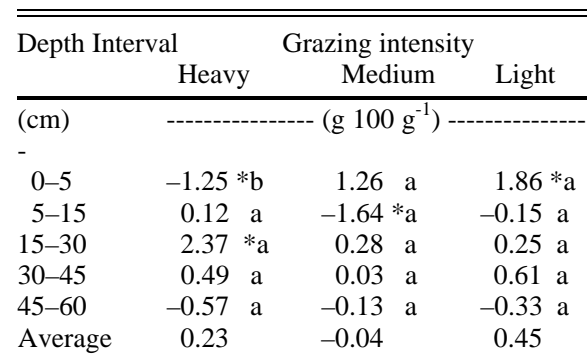

Means followed by an asterisk are significantly $(\mathrm{P} \leq 0.05)$ different than their corresponding pre-grazing values (t-test). Row means followed by different small letters indicate significant differences among grazing intensities (LSD test).

compaction observed in a concurrent study (Mapfumo et al. 1999) may have reduced macro-porosity and thus AWHC at low moisture tension.

\section{Chemical and Nutrient Properties}

Total soil nitrogen content in all depths and treatments ranged between 0.06 and

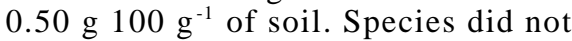
affect soil $\mathrm{N}$ content. Generally grazing altered soil $\mathrm{N}$ content between 0 and 30 $\mathrm{cm}(\mathrm{P} \leq 0.05)$ (Table 3). Averaged over all depths the change in $\mathrm{N}$ content was positive in all 3 grazing treatments.

Table 4. Change in potassium content $\left(\mathrm{mg} \mathrm{kg}^{-1}\right)$ after 3 years relative to corresponding pre-grazing values for different grazing intensities, plant species and soil depths.

\begin{tabular}{|c|c|c|c|c|}
\hline \multirow[t]{2}{*}{ Depth Interval } & \multirow[b]{2}{*}{ Depth } & \multicolumn{3}{|c|}{ Grazing intensity } \\
\hline & & Heavy & Medium & Light \\
\hline & $(\mathrm{cm})$ & \multicolumn{3}{|c|}{$\left(\mathrm{g} 100 \mathrm{~g}^{-1}\right)$} \\
\hline Smooth bromegrass & $0-5$ & $63 \mathrm{aA}$ & $18 \mathrm{aA}$ & $139 \mathrm{aA}$ \\
\hline Meadow bromegrass & & $64 * \mathrm{aA}$ & $15 \mathrm{aA}$ & -22 aA \\
\hline Barley/triticale & & $121 \mathrm{aA}$ & -6 aA & $100 \mathrm{aA}$ \\
\hline Triticale & & $40 \mathrm{aA}$ & 25 aA & $12 \mathrm{aA}$ \\
\hline Smooth bromegrass & $5-15 \mathrm{~cm}$ & $30 \mathrm{aA}$ & $119 \mathrm{aA}$ & $32 \mathrm{aA}$ \\
\hline Meadow bromegrass & & $57 \mathrm{aA}$ & $10 \mathrm{aA}$ & $41 \mathrm{aA}$ \\
\hline Barley/triticale & & 35 aA & 28 aA & $85 * \mathrm{aA}$ \\
\hline Triticale & & $7 \mathrm{aA}$ & $71 * \mathrm{aA}$ & $11 \mathrm{aA}$ \\
\hline Smooth bromegrass & $15-30 \mathrm{~cm}$ & $-17 \mathrm{aA}$ & $4 \mathrm{aA}$ & $25 \mathrm{aA}$ \\
\hline Meadow bromegrass & & $30 \mathrm{aA}$ & $-12 \mathrm{aA}$ & $-11 \mathrm{aA}$ \\
\hline Barley/triticale & & -3 aA & $-2 \mathrm{aA}$ & $20 \mathrm{aA}$ \\
\hline Triticale & & $14 \mathrm{aA}$ & $4 \mathrm{aA}$ & -4 aA \\
\hline Smooth bromegrass & $30-45 \mathrm{~cm}$ & $-7 \mathrm{aB}$ & $6 \mathrm{aA}$ & $3 \mathrm{aB}$ \\
\hline Meadow bromegrass & & $22 \mathrm{aA}$ & $0 \mathrm{bA}$ & $0 \mathrm{bB}$ \\
\hline Barley/triticale & & $0 \mathrm{bB}$ & $1 \mathrm{bA}$ & $25 \mathrm{aA}$ \\
\hline Triticale & & $3 \mathrm{aB}$ & $0 \mathrm{aA}$ & $2 \mathrm{aB}$ \\
\hline Smooth bromegrass & $45-60 \mathrm{~cm}$ & $1 \mathrm{aA}$ & 8 aA & $4 * \mathrm{aA}$ \\
\hline Meadow bromegrass & & $0 \mathrm{aA}$ & $-2 \mathrm{aA}$ & $15 \mathrm{aA}$ \\
\hline Barley/triticale & & $5 \mathrm{aA}$ & 5 aA & $6 \mathrm{aA}$ \\
\hline Triticale & & $9 \mathrm{aA}$ & $2 \mathrm{aA}$ & $4 \mathrm{aA}$ \\
\hline
\end{tabular}

Means followed by an asterisk are significantly $(\mathrm{P} \leq 0.05)$ different than their corresponding pre-grazing values ( $\mathrm{t}-$ test $)$ Row means followed by different lower case letters indicate significant difference among grazing intensities (LSmeans, $\mathrm{P} \leq 0.05$ ) within species. Column means followed by upper case letters indicate significant difference among species (LSmeans, $\mathrm{P} \leq 0.05$ ) within grazing intensity. 


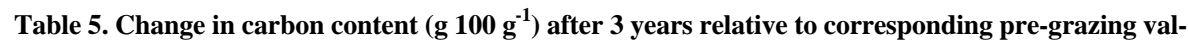
ues under different plant species at different soil depths. Values pooled over grazing intensities.

\begin{tabular}{lcccc}
\hline \hline $\begin{array}{l}\text { Depth } \\
\text { interval }\end{array}$ & $\begin{array}{c}\text { Smooth } \\
\text { bromegrass }\end{array}$ & $\begin{array}{c}\text { Meadow } \\
\text { bromegrass }\end{array}$ & $\begin{array}{c}\text { Barley/ } \\
\text { Triticale }\end{array}$ & Triticale \\
\hline$(\mathrm{cm})$ & $--12 \mathrm{a}$ & $0.08 \mathrm{a}$ & $-0.29 * \mathrm{~b}$ & $-0.39 * \mathrm{~b}$ \\
$0-5$ & $0.12 \mathrm{a}$ & $-0.12 \mathrm{a}$ & $0.12 \mathrm{a}$ & $-0.04 \mathrm{a}$ \\
$5-15$ & $0.22 \mathrm{a}$ & $-0.36 \mathrm{a}$ & $-0.09 \mathrm{a}$ & $-0.31 \mathrm{a}$ \\
$15-30$ & $-0.10 \mathrm{a}$ & $-0.48 * \mathrm{a}$ & $-0.42 * \mathrm{a}$ & $-0.29 \mathrm{a}$ \\
$30-45$ & $-0.05 \mathrm{a}$ & $-0.17 \mathrm{a}$ & $0.00 \mathrm{a}$ & $-0.09 \mathrm{a}$ \\
$45-60$ & 0.08 & -0.21 & -0.14 & -0.22 \\
\hline Average & 0.14 & $\left.\mathrm{~g}^{-1}\right)$ & \\
\hline
\end{tabular}

Means followed by an asterisk are significantly $(\mathrm{P} \leq 0.05)$ different than their corresponding pre-grazing values (t-test). Row means followed by different small letters indicate significant differences among grazing intensities (LSD test).

treatment had the largest change in $\mathrm{K}$ content compared to other treatments.

Soil carbon content generally ranged between 3 and $6 \mathrm{~g} 100 \mathrm{~g}^{-1}$ of soil for depth intervals between 0 and $30 \mathrm{~cm}$, and from

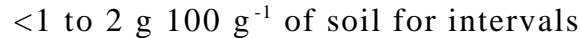
between 30 and $60 \mathrm{~cm}$. Change in soil carbon $(\mathrm{C})$ content after 3 years of grazing was not significantly affected by grazing intensity, but was affected by forage species only for the $0-5 \mathrm{~cm}$ depth interval (Table 5). Soil carbon content under perennials slightly increased after 3 years of grazing whereas under annuals soil carbon content decreased. These differences may be attributed to a combination of opposing factors; yearly cultivation of annuals which likely promoted organic matter decomposition, and accumulation of litter under perennials which likely increased soil carbon. In perennials, annual cultivation was not conducted such that rate of litter incorporation into the soil carbon pool was most likely greater than the rate of organic matter breakdown. In spite of the differences in change in carbon content among species, grazing intensity or forage species did not affect the change in carbon-tonitrogen $(\mathrm{C}: \mathrm{N})$ ratio. For all grazing intensities, forage species and soil depths, $\mathrm{C}: \mathrm{N}$ ratios ranged between 9:1 to 18:1.

Electrical conductivities (EC) ranged between 0.16 and $0.75 \mathrm{dS} \mathrm{m}^{-1}$ for depth intervals between 0 and $30 \mathrm{~cm}$ and between 0.12 and $0.30 \mathrm{dS} \mathrm{m}^{-1}$ for depths between 30 and $60 \mathrm{~cm}$. Change in EC was significantly influenced by forage species for the 5-15, 15-30, and 30-45 cm intervals. Barley/triticale had a greater increase in electrical conductivity compared to meadow bromegrass (Table 6). However smooth bromegrass had a similar change in EC to meadow bromegrass, barley/triticale and triticale. Grazing intensity also influenced change in EC for all depth intervals between 15 and $60 \mathrm{~cm}$. The heavy grazing treatment had a significantly greater increase in EC than medium or light grazing. Averaged over all depths the grazing intensities (LSD test).

\section{Discussion}

The small differences in water retention among grazing treatments generally reflect the minimal impacts of grazing, regardless of grazing intensity, on soil parameters evaluated in this study. Results from a concurrent study also indicate minimal grazing effects on soil bulk density, relative compaction (Mapfumo et al. 1999) and water-stable aggregate size distribution (Mapfumo 1997).

The carbon:nitrogen ratio reflects the potential for soils to mineralize and immobilize $\mathrm{N}$. Generally a $\mathrm{C}: \mathrm{N}$ ratio less than 20:1 indicates a potential for net mineralization whereas $\mathrm{C}: \mathrm{N}$ ratio greater than 30:1 indicates potential immobilization (Tisdale et al. 1993). In our study, for all grazing levels, plant species and years, $\mathrm{C}: \mathrm{N}$ ratios were less than $20: 1$, suggesting that $\mathrm{N}$ release through mineralization likely occurred. This process results in increased mineral nitrogen $\left(\mathrm{NH}_{4}-\mathrm{N}\right.$ and $\mathrm{NO}_{3}-\mathrm{N}$ ) which may contribute to increased solute concentration and hence electrical conductivity (EC) of the soil solution.

Extractable $\mathrm{K}$ includes soil solution $\mathrm{K}$ as well as $\mathrm{K}$ that is adsorbed onto exchange sites on the clay surfaces (exchangeable $\mathrm{K})$. It is difficult to ascertain why grazing and forage species had an interactive effect only for the $30-45 \mathrm{~cm}$ interval. However, processes such as leaching, fixation by micaceous clays, weathering of feldspars and crop uptake occur concurrently and are known to affect exchangeable K (Tisdale et al. 1993). Changes in

\section{Table 6. Change in electrical conductivity $\left(\mathrm{dS} \mathrm{m}^{-1}\right)$ after 3 years relative to corresponding pre-graz- ing values under different plant species (pooled over grazing intensities) and under different grazing intensities (pooled over different plant species) at different soil depths.}

\begin{tabular}{|c|c|c|c|c|}
\hline $\begin{array}{l}\text { Depth } \\
\text { interval }\end{array}$ & $\begin{array}{c}\text { Smooth } \\
\text { bromegrass }\end{array}$ & $\begin{array}{c}\text { Meadow } \\
\text { bromegrass }\end{array}$ & $\begin{array}{l}\text { Barley/ } \\
\text { Triticale }\end{array}$ & Triticale \\
\hline$(\mathrm{cm})$ & \multicolumn{4}{|c|}{ 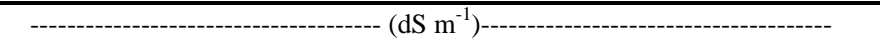 } \\
\hline $0-5$ & -0.09 a & $-0.27 * \mathrm{a}$ & $-0.25 * b$ & $-0.08 * \mathrm{a}$ \\
\hline $5-15$ & $0.22 * a b$ & $0.11 * b$ & $0.27 * \mathrm{a}$ & $0.15 * b$ \\
\hline $15-30$ & $0.20 * a b$ & $0.11 * b$ & $0.27 * \mathrm{a}$ & $0.18 * a b$ \\
\hline $30-45$ & $0.19 * a b$ & $0.11 * \mathrm{~b}$ & $0.23 * \mathrm{a}$ & $0.15 * b$ \\
\hline $45-60$ & $0.10 * \mathrm{a}$ & $0.06 * a$ & $0.14 * \mathrm{a}$ & $0.09 * \mathrm{a}$ \\
\hline Average & 0.12 & 0.02 & 0.13 & 010 \\
\hline
\end{tabular}

\begin{tabular}{|c|c|c|c|}
\hline \multirow{2}{*}{$\begin{array}{l}\text { Depth } \\
\text { interval }\end{array}$} & \multicolumn{3}{|c|}{ Grazing intensity } \\
\hline & \multicolumn{3}{|c|}{ - } \\
\hline $0-5$ & $-0.03 * \mathrm{a}$ & $-0.25 * \mathrm{a}$ & $-0.23 * \mathrm{a}$ \\
\hline $5-15$ & $0.36 * \mathrm{a}$ & $0.12 * b$ & $0.08 * \mathrm{~b}$ \\
\hline $15-30$ & $0.29 * \mathrm{a}$ & $0.17 * b$ & $0.11 * b$ \\
\hline $30-45$ & $0.24 * \mathrm{a}$ & $0.12 * b$ & $0.14 * b$ \\
\hline $45-60$ & $0.16 * \mathrm{a}$ & $0.06 * b$ & $0.07 * \mathrm{~b}$ \\
\hline Average & 0.20 & 0.04 & 0.03 \\
\hline
\end{tabular}

Means followed by an asterisk are significantly $(\mathrm{P} \leq 0.05)$ different than their corresponding pre-grazing values (t-test). Row means followed by different small letters indicate significant differences among plant species and among 
Table 7. Change in soil pH after 3 years relative to corresponding pre-grazing values under different plant species (pooled over grazing intensities) and under different grazing intensities (pooled over different plant species) at different soil depths.

\begin{tabular}{lcccc}
\hline \hline $\begin{array}{l}\text { Depth } \\
\text { interval }\end{array}$ & $\begin{array}{c}\text { Smooth } \\
\text { bromegrass }\end{array}$ & $\begin{array}{c}\text { Meadow } \\
\text { bromegrass }\end{array}$ & $\begin{array}{c}\text { Barley/ } \\
\text { Triticale }\end{array}$ & Triticale \\
\hline$(\mathrm{cm})$ & $0.16 * \mathrm{a}$ & $0.12 * \mathrm{a}$ & $-0.06 * \mathrm{~b}$ & $0.04 * \mathrm{ab}$ \\
$0-5$ & $0.04 * \mathrm{a}$ & $0.03 * \mathrm{a}$ & $-0.18 * \mathrm{~b}$ & $0.04 * \mathrm{a}$ \\
$5-15$ & $0.18 \mathrm{a}$ & $0.20 \mathrm{a}$ & $0.13 \mathrm{a}$ & $0.18 \mathrm{a}$ \\
$15-30$ & $0.04 * \mathrm{a}$ & $0.11 * \mathrm{a}$ & $-0.01 * \mathrm{a}$ & $0.04 * \mathrm{a}$ \\
$30-45$ & $-0.06 * \mathrm{a}$ & $0.00 * \mathrm{a}$ & $-0.23 * \mathrm{~b}$ & $-0.12 * \mathrm{ab}$ \\
$45-60$ & 0.07 & 0.09 & -0.07 & 0.04 \\
Average & &
\end{tabular}

\begin{tabular}{lrcr}
\hline \hline $\begin{array}{l}\text { Depth } \\
\text { interval }\end{array}$ & Heavy & $\begin{array}{c}\text { Grazing intensity } \\
\text { Medium }\end{array}$ & Light \\
\hline$(\mathrm{cm})$ & & $0.02 * \mathrm{a}$ & $0.11 * \mathrm{a}$ \\
$0-5$ & $0.08 * \mathrm{a}$ & $0.05 * \mathrm{a}$ & $0.07 * \mathrm{a}$ \\
$5-15$ & $-0.17 * \mathrm{~b}$ & $0.18 \mathrm{a}$ & $0.21 \mathrm{a}$ \\
$15-30$ & $0.13 \mathrm{a}$ & $0.07 * \mathrm{a}$ & $0.10 * \mathrm{a}$ \\
$30-45$ & $-0.04 * \mathrm{a}$ & $-0.04 * \mathrm{a}$ & $-0.12 * \mathrm{a}$ \\
$45-60$ & $-0.15 * \mathrm{a}$ & 0.06 & 0.07 \\
Average & -0.03 & &
\end{tabular}

Means followed by an asterisk are significantly $(\mathrm{P} \leq 0.05)$ different than their corresponding pre-grazing values (t-test). Row means followed by different small letters indicate significant differences among plant species and among grazing intensities (LSD test).

soil macroporosity and rooting patterns might influence preferential flow paths and fertilizer distribution. Annuals might uptake more $\mathrm{K}$ before it leaches very far.

Changes in soil $\mathrm{pH}$ among grazing treatments within species were small $(\leq 0.20$ units), and soil depth seemed to have more influence on $\mathrm{pH}$ than either plant species or grazing level. However, the decrease in soil $\mathrm{pH}$ after 3 years of heavy grazing obtained for the $5-15 \mathrm{~cm}$ interval may be due to increased $\mathrm{NH}_{4}-\mathrm{N}$ from dung and urine depositions, which through nitrification produced $\mathrm{NO}_{3}-\mathrm{N}$ plus hydrogen ions. In fact results from a concurrent study indicate that both mineral $\mathrm{N}$ and $\mathrm{NO}_{3}-\mathrm{N}$ levels were greater under heavy compared to medium and light grazing (Baron et al. unpublished data). Estimates of urine loading rates from that study were 18,615 , 10,075 and $7,919 \mathrm{~L} \mathrm{~h}^{-1} \mathrm{yr}^{-1}$ for heavy medium and light grazing, respectively with dung loading estimates for the respective grazing intensities of 1489, 806 and $634 \mathrm{~kg} \mathrm{DM} \mathrm{ha}^{-1} \mathrm{yr}^{-1}$. The lack of soil $\mathrm{pH}$ differences among grazing intensities for the surface $(0-5 \mathrm{~cm})$ interval can be partly attributed to $\mathrm{NH}_{3}-\mathrm{N}$ loss from fresh cattle wastes through volatilization which some researchers have reported to be more than $50 \%$ only three days after deposition (Westerman et al. 1985). Despite the observed changes after 3 years of grazing, the soil $\mathrm{pH}$ remained within the nonrestrictive range for growth of annual or perennial grasses. Overall, if we assume a constant rate of change of $\mathrm{pH}$ over time it would take at least 15 years to effect a unit change in soil $\mathrm{pH}$.
Electrical conductivity in all treatments was between 0 and $2 \mathrm{dS} \mathrm{m} \mathrm{m}^{-1}$, which is the range within which salinity has negligible effects on plant growth (Bernstein 1975). The greater increase in EC under heavy compared to medium and light grazing treatments for depth intervals between 15 and $60 \mathrm{~cm}$, may have been due to a combination of yearly application of fertilizer, increased urine and dung loading rates as well as organic- $\mathrm{N}$ mineralization to produced mineral $\mathrm{N}$. These processes are known to increase total solutes in soil solution which is directly related to electrical conductivity.

In general, grazing intensity nor the type of forage grazed has insignificant effects on the soil parameters measured after three years of grazing. These early results may be refined after comparisons are made following 10 to 20 years of treatments.

Baron, V.S., E. Mapfumo, M.A. Naeth, and D.S. Chanasyk. 1999. Sustainable grazing systems for perennial and annual forages on sloped lands. Canada-Alberta Environmentally Sustainable Agr. Agreement Final Rep. 161 pp.

Baron, V.S., H.G. Nadja, D.F. Salmon, J.R. Pearen, and A.C Dick. 1993. Cropping systems for spring and winter cereals under simulated pasture: sward structure. Can. J. Plant Sci. 73:947-959.

Bernstein, L. 1975. Effects of salinity and sodicity on plant growth. Ann. Rev. Phytopathol. 13:295-312.

Bransby, D.I., A.G. Matches, and G.F. Krause. 1977. Disk meter for rapid estimation of herbage yield in grazing trials. Agron. J. 69:393-396.

\section{References}

Broersma, K. 1991. The effects of different cropping systems on a luvisolic soil in the Peace River region. Ph.D. Diss., Univ. Alberta, Edmonton, Canada.

Chaneton, E.J. and R.S. Lavado. 1996. Soil nutrients and salinity after long-term grazing exclusion in a Flooding Pampa grassland. J. Range Manage. 49:182-187.

Dormaar, J.F. and W.D. Willms. 1990. Effect of grazing and cultivation on some chemical properties of soils in the mixed prairie. J. Range Manage. 43:456-460.

Dormaar, J.F., S. Smoliak, and W.D. Willms. 1989. Vegetation and soil responses to shortduration grazing on fescue grasslands. J. Range Manage. 42:252-256.

Gomez, K.A. and A.A. Gomez. 1984. Statistical procedures for agricultural research. John Wiley and Sons, New York, N.Y.

Hendershot, W.H., H. Lalande, and M. Duquette. 1993. Ion exchange and exchangeable cations, p. 167-176. In: M.R. Carter (ed.), Soil sampling and methods of analysis. Lewis Publishers, Boca Raton, Fla.

Holland, E.A. and J.K. Detling. 1990. Plant response to herbivory and belowground nutrient cycling. Ecol. 71:1040-1049.

Janzen, H.H. 1993. Soluble salts, p 161-166. In: M.R. Carter (ed.), Soil sampling and methods of analysis. Lewis Publishers, Boca Raton, Fla.

Johnston, A., J.F. Dormaar, and S. Smoliak. 1971. Long-term grazing effects on fescue grassland soils. J. Range Manage. 24:185-188.

Krenzer Jr., E.G., C.F. Chee, and J.F. Stone 1989. Effects of animal traffic on soil compaction in wheat pastures. J. Prod. Agr. 2:246-249.

Lagroix-McLean, R.L. and M.A. Naeth. 1997. Forages in the aspen parkland, A literature and data review. Final Report Prepared for Ducks Unlimited Canada, North Amer. Waterfowl Manage. Plan and Conservation and Dev. Branch. Dep. of Renewable Resources, Univ. Alberta, Edmonton, Canada.

Mapfumo, E. 1997. Soil and plant response to compaction. Ph.D. Diss., Univ. Alberta, Edmonton, Canada.

Mapfumo, E., D.S. Chanasyk, M.A. Naeth, and V.S. Baron. 1999. Soil compaction under grazing of annual and perennial forages. Can. J. Soil Sci. 79:191-199.

McGill, W.B. and C.T. Figuerido. 1993. Total nitrogen, p. 201-212. In: M.R. Carter (ed.), Soil sampling and methods of analysis. Lewis Publishers, Boca Raton, Fla.

SAS Institute 1989. SAS/STAT user's guide. SAS Inst., Cary, N.C.

Tisdale, S.L., W.L. Nelson, J.D. Beaton, and J.L. Havlin. 1993. Soil fertility and fertilizers. McMillan Publ. Co., New York.

Topp, G.C., Y.T. Galganov, B.C. Ball, and M.R. Carter. 1993. Soil water desorption curves, p. 569-580. In: M.R. Carter (ed.), Soil sampling and methods of analysis, Lewis Publ., Boca Raton, Fla.

Westerman, P.W., L.M. Safley Jr., J.C. Barker, and G.M. Chescheir. 1985. Available nutrients in livestock waste. Agr. Waste Utiliz. and Manage. Proc. Fifth Int. Symp. Agr. Wastes, Dec. 16-17, Chicago, Ill. 